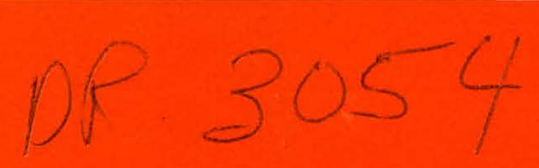

July 1979

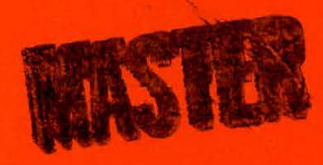

\title{
A Preliminary Report on the Agricultural Sector Impacts of Obtaining Ethanol from Grain
}

Donald I. Hertzmark
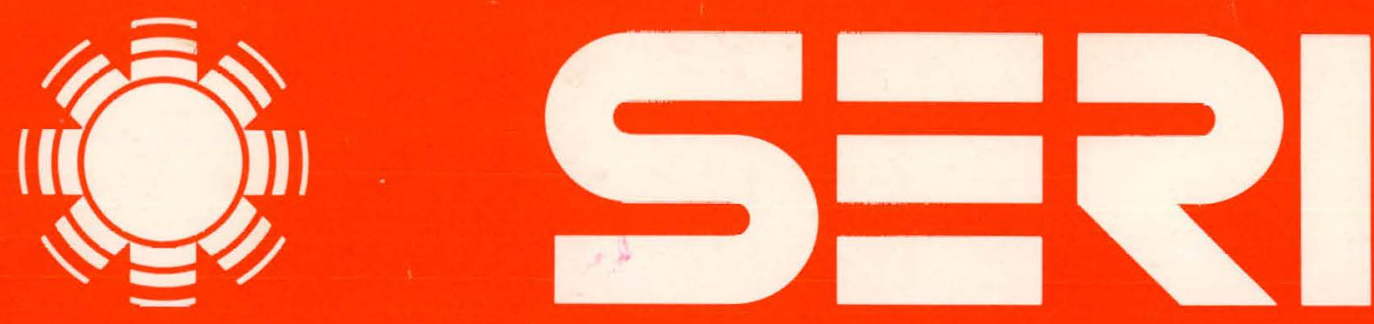

Solar Energy Research Institute A Division of Midwest Research Institute

1536 Cole Boulevard

Golden, Colorado 80401

Operated for the U.S. Department of Energy under Contract No. EG-77-C-01-4042

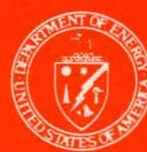




\section{DISCLAIMER}

This report was prepared as an account of work sponsored by an agency of the United States Government. Neither the United States Government nor any agency Thereof, nor any of their employees, makes any warranty, express or implied, or assumes any legal liability or responsibility for the accuracy, completeness, or usefulness of any information, apparatus, product, or process disclosed, or represents that its use would not infringe privately owned rights. Reference herein to any specific commercial product, process, or service by trade name, trademark, manufacturer, or otherwise does not necessarily constitute or imply its endorsement, recommendation, or favoring by the United States Government or any agency thereof. The views and opinions of authors expressed herein do not necessarily state or reflect those of the United States Government or any agency thereof. 


\section{DISCLAIMER}

Portions of this document may be illegible in electronic image products. Images are produced from the best available original document. 
Printed in the United States of America

Available from:

National Technical Information Service

U.S. Department of Commerce

5285 Port Royal Road

Springfield, VA 22161

Price:

Microfiche $\$ 3.00$

Printed Copy $\$ 4.00$

NOTICE

This report was prepared as an account of work sponsored by the United States Government. Neither the United States nor the United States Department of Energy, nor any of their employees, nor any of their contractors, subcontractors, or their employees, makes any warranty, express or implied, or assumes any legal liability or responsibility for the accuracy, completeness or usefulness of any information, apparatus, product or process disclosed, or represents that its use would not infringe privately owned rights. 
SERI /RR-51-292

UC CATEGORY: UC-61

\section{MASTER}

A PRELIMINARY REPORT ON THE

AGRICULTURAL SECTOR IMPACTS OF

OBTAINING ETHANOL FROM GRAIN

DONALD I. HERTZMARK

JULY 1979

This report was prepared as an account of work sponsored by the United Slates Ened Sur hor the United States Lepartment of Energy, nor any of their employees, nor any of their contractors, subcontractors, of their employees, makes any warranty, express or implied, or assumet any logal liability or responsibility for the accuracy, completeness or usefulness of any information, apparatus, product or process disclosed, or represents that its use would iot infringe privately owned rights.

PREPARED UNDER TASK NO. 3321.30

\section{Solar Energy Research Institute}

1536 Cole Boulevard

Golden, Colorado 80401

ADivision of Midwest Research Institute

Prepared for the U.S. Department of Energy

Contract No. EG $\cdot 77 \cdot \mathrm{C} \cdot 01 \cdot 4042$ 
THIS PAGE

\section{WAS INTENTIONALLY \\ LEFT BLANK}




\section{FOREWORD}

This report was prepared as a part of SERI task number 3321.3, Gasohol Policy Analysis. This work is supported by the Biomass Energy Systems Branch of the Office of Energy Technology, U.S. Department of Energy. The report describes some of the preliminary results that affect such issues as the balance of payments and energy import impacts of obtaining liquid fuels from agricultural crops. This report is a precursor to a more detailed and comprehensive look at these and other issues such as food price impacts and farm income impacts that will come in Fall 1979. Policy issues related to this work concern farm income and production programs and tax and subsidy schemes for the end products.

The leader for this subtask is Donald I. Hertzmark of SERI's Policy Analysis Branch. The overall direction of the economic analysis of Biomass fuels is performed by Silvio Flaim of the Economic Analysis Branch.

The author acknowledges the helpful comments on this report off ered by Melvin Simmons and Silvio Flaim of SERI.

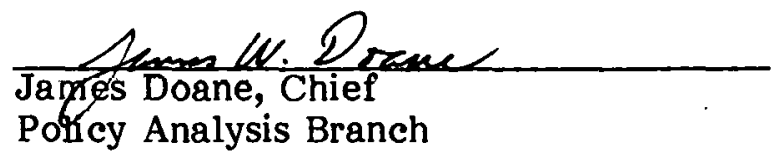

Approved for

SOLAR ENEKGYY RESEARCH INSTITUTE

Melvin K. Simmons, Assistant Director

Anälysis Division

iii 
THIS PAGE

WAS INTENTIONALLY

LEFT BLANK 


\section{TABLE OF CONTENTS}

Page

1.0 Introduction $\ldots \ldots \ldots \ldots \ldots \ldots \ldots \ldots \ldots \ldots \ldots \ldots \ldots \ldots \ldots \ldots \ldots \ldots \ldots$

2.0 Energy and Materials Balance Analysis ...................... 3

3.0 Agricultural Policy and Food Production Impacts $\ldots \ldots \ldots \ldots \ldots \ldots \ldots \ldots$

3.1 Agricultural Policy .............................. 14

3.2 Limitations .................................. 15

4.0 Conclusions $\ldots \ldots \ldots \ldots \ldots \ldots \ldots \ldots \ldots \ldots \ldots \ldots \ldots \ldots \ldots \ldots \ldots \ldots \ldots$

Ref erences ...................................... 19

Appendix. The Markets for Distillers' By-products ............... 21 


\section{THIS PAGE}

\section{WAS INTENTIONALLY \\ LEFT BLANK}


SEP IV

RR-292

LIST OF TABLES

$\underline{\text { Page }}$

2-1 Grain-to-Alcohol Production Relations

3

2-2 Energy Analysis of Ethanol Manufacture.

4

3-1 Domestic and Export Demand. Elasticities for Food and Feed Grains.

8

3-2 U.S. Grain and Feed Exports, 1974-76

9

3-3 Value of U.S. Grain and Feed Exports, $1974-76 \ldots \ldots \ldots \ldots \ldots \ldots \ldots \ldots$

-3-4 Energy-Import Tradeoffs of a Gasohol Program with Export of DDG....... 11

3-5 Net Liquid Energy Trade Imports of a Gasohol Program as Above......... i 12

3-6 Cost Elasticity of Ethanol

15

4-1 U.S. Synthetic Alcohol Production and Consumption

17

vii 


\section{SECTION 1.0}

\section{INTRODUCTION}

Obtaining liquid energy from crops, residues, or other renewable resources has become a major research effort in the United States and several other countries, most notably Brazil and Canada. The rationale has been the same in the three countries; namely, to reduce imports of fuel through the use of an agricultural or forestry product that is overabundant relative to the production capacity for that crop at current price-cost ratios and the effective demand that the crop faces. From the point of view of energy policy, the overall objective is to minimize the imports of energy products. A secondary objective is the relaxation of the excess demands on liquid fuels via substitution for either gasoline or ethylene. The constraints that are placed on the achievement of these objectives from agricultural sources are several. The first is agricultural policy which seeks generally to maintain stability in the agricultural sector of the economy. This precludes a quick response to temporary imbalances in fuel markets. Second, the basic infrastructure of the alcohol industry takes time to develop. Third, increased demand for agricultural output can be accommodated by more intensive cultivation (i.e., shif ts from lower to higher value crops-the intensive margin) and by the cultivation of additional croplands (the extensive margin). At the extensive margin, the energy inputs to agriculture become crucial since the energy requirements of less productive land are greater relative to output than those for higher quality land (this is especially true for land that requires irr igation).

These shif ts at the intensive and extensive margins of cultivation must naturally be accompanied by higher unit costs of production which becomes the final constraint; namely, large increases in farm commodity prices will reduce export earnings in the medium term due to the elasticities of foreign demand. Since export earnings will be needed to pay for energy imports into the foreseeable future, policies to encourage the production of energy from agriculture should be productive in terms of overall energy supply.

Of particular concern, therefore, is the question of the material and energy balances for both crop production and conversion of the crop to a fuel-plus-feed by-product. If the entire process is heavily consumptive of liquid-energy products, then its net yield of liquid fuels is insignificant. In eff ect, one type of liquid fuel would be converted to another type for no particular net benefit. Another major area of concern is agricultural policy. The United States is currently the world's largest food exporter; energy policies that reduce the quantities of grain and feed available for export will have a definite impact on the prices of foods and feeds worldwide.

The types of relationships that dominate the interactions of agricultural and energy policies are traced in this paper. The question of the availability of additional croplands for energy crop production will be mentioned only briefly since definitive answers are lacking as to the interactions of economic, environmental, and technological factors that influence the estimates of the additional land that is available. Other areas that are covered insufficiently in this paper pertain to the conversion of waste products of urban or agricultural origin to liquid fuels. The technology for a waste conversion is presently in the pilot plant stage so that the relative costs are not yet settled for production, feed stocks, or by-products. 


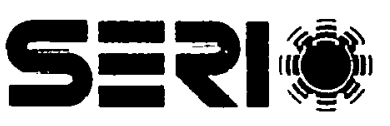




\section{SECTION 2.0}

\section{ENERGY AND MATERIALS BALANCE ANALYSIS}

The conversion of grain crops to alcohol is an ancient technology used throughout the world. The basic production relations are governed by the relative fixity of the outputs in relation to one another. As shown in Table 2-1, preprocessing of the grain yields at least three by-products (corn oil, gluten meal, and distillers' dried grains) that may be advantageous in terms of marketing flexibility of the products. Energy consumption in the conversion process is a problematic area and serves to point out many of the weaknesses of net energy analysis for the purposes of policy. The major importance of energy analysis is in the assessment of the liquid fuels balance since that is perceived as being the crucial area for which alcohol can contribute to U.S. energy needs.

Table 2-1. GRAIN-TO-ALCOHOL PRODUCTION RELATIONS ${ }^{a}$

\begin{tabular}{|c|c|c|c|c|c|c|c|}
\hline \multirow{2}{*}{$\begin{array}{l}\text { Beverage } \\
\text { Industry } \\
\text { Technique }\end{array}$} & Corn In & \multicolumn{4}{|c|}{ Ethanol Out } & \multicolumn{2}{|c|}{$\begin{array}{l}\text { By-Products } \\
\text { (Distillers } \\
\text { Dried Grains) }\end{array}$} \\
\hline & $1 \mathrm{bu} 100 \mathrm{~kg}$ & & & $37.4 \&$ & & $18 \mathrm{lb}$ & $32.1 \mathrm{~kg}$ \\
\hline & Corn In & \multicolumn{2}{|c|}{ Ethanol } & \multicolumn{2}{|c|}{ Corn Oil } & \multicolumn{2}{|c|}{ Gluten \& DDG } \\
\hline $\begin{array}{l}\text { Corn } \\
\text { Processing } \\
\text { Technique }\end{array}$ & $1 \mathrm{bu} \quad 100 \mathrm{~kg}$ & $2.5 \mathrm{gal}$ & $37.4 \ell$ & $3 \mathrm{lb}$ & $5.4 \mathrm{~kg}$ & $12 \mathrm{lb}$ & $21.4 \mathrm{~kg}$ \\
\hline
\end{tabular}

$a_{[1,2] \text {. }}$

Unfortunately, there is no unambiguous result from the energy analysis. Different accounting stances and widely divergent figures on the actual energy consumption of the processes to convert grain to ethanol make this a murky subject at best. In addition to the uncertainty about the process-energy consumption, there is a considerable difference in the energy use at the farm level for the growing of the crop itself due to differences in soil type, rainfall, crop management, and land quality. Supporting data for this assertion come from Litterman, Eidman, Jensen (1978), p. 25. However, intuition confirms this since, by definition, low quality land is less efficient at converting the inputs of energy, water, chemicals, and sunlight to food energy than is high quality land. With all of these caveats in mind, we may now proceed to the energy analysis.

The technique of net energy analysis derives from the first law of thermodynamics and is given by the formula

$$
\eta=\frac{\text { energy out }}{\text { energy in (excluning solar) }} \quad 1
$$


The conventions of energy analysis are not universally accepted with major areas of disagreement centering on how to count (or not count) renewable sources, aggregate across various energy types, and value final outputs [3].

The first method is to sum all of the outputs ethanol and DDG and divide by the sum of the inputs corn energy and growing energy and processing energy. This gives a range of net energy ratios of .38 to .83 according to the ranges in the data given in Table 2-2. A similar exercise for gasoline would show no higher efficiencies than the better of these ratios. An alternative method is to ignore the values for corn and DDGS and to look at the energy input as growing and processing and the energy output as the ethanol only. This method yields ratios of .39 to 1.7 . If we assume a $1: 1$ ethanol for gasoline substitution then the range narrows to .64 to 1.7 .

Table 2-2. ENERGY ANALYSIS OF ETHANOL MANUFACTURE ${ }^{\circledR}$

\begin{tabular}{|c|c|c|}
\hline & Btu/bil & $\mathrm{Mj} / \mathrm{kg}$ \\
\hline \multicolumn{3}{|l|}{ Energy in } \\
\hline $\begin{array}{l}\text { Corn } \\
\text { (Stover) }\end{array}$ & $\begin{array}{c}377,000 \\
(377,000)\end{array}$ & 15.7 \\
\hline Growing Corn & $107,405-188,000^{b}$ & $4.5-7.8$ \\
\hline Processing & $100,000-350,000$ & $105.5-369.3$ \\
\hline Electricity & $4,120-7,700$ & $.17-.32$ \\
\hline \multicolumn{3}{|l|}{ Energy Out } \\
\hline Ethanol & $211,000-345,130^{c}$ & $8.8-14.3$ \\
\hline DDGS & 110,400 & 5.8 \\
\hline \multicolumn{3}{|c|}{${ }^{a}$ Assume 2.5 gal. ETOH/bu $[4,5]$. } \\
\hline \multicolumn{3}{|c|}{$\begin{array}{l}{ }^{b} \text { The first number in the range is the U.S. average; the second } \\
\text { number is for relatively poor (arid, poor soil) land. }\end{array}$} \\
\hline \multicolumn{3}{|c|}{$\begin{array}{l}\mathrm{C}_{\text {The first number in the range is the actual heat valuc of cthanol, }} \\
\text { the second number is the value attributed to the ethanol if it is }\end{array}$} \\
\hline
\end{tabular}

What are we to make of these net energy ratios? The answers are ambiguous for a technique that purports to be aimed at feasibility analysis. One final element of confusion is the possibility of using stover as the energy source for processing. If this is done, the overall fossil energy balance would prove to be unambiguously positive sine only growing entergy would remain on the input side. Given the tremendous range of possible combinations of inputs and outputs, it is not surprising that energy analysis has led to such controversy and contradiction. Perhaps the most constructive use of energy analysis in this case is to look strictly at liquid energy balances. This shows a positive net liquid energy balance even for poor croplands (assuming that all growing energy is liquid or gaseous). This, then, is the technical feasibility criterion that matters since the purpose of the program is liquid fuels production.

From the viewpoint of the objectives of producing energy from biomass we need to note that the notion of efficiency relates to the substitution for imported oil. Thus, the 
opport unity costs of choosing to go the biomass route include reduced emphasis on shale, coal liquefaction, and methanol from coal as alternatives. To say that biomass is more efficient at producing liquid energy products than the above named alternatives is to assert that the overall yield of liquid energy is greater per dollar invested. The existence of a deadweight loss in agriculture, such as the money that is paid to farmers for not growing crops, provides the type of slack that gives biomass at least an initial advantage over the alternatives. This is because the opportunity costs of producing energy crops on set-aside lands is zero or negative.

An additional problem with energy analysis in its simple form concerns the issue of energy quality. As argued above, one of the major objections to energy analysis is its aggregation over the forms in which energy is available-liquid, solid, gaseous. A more essential objection, however, concerns the issue of quality in the thermodynamic sense.

The energy analysis presented above carries with it the assumption that all joules are equivalent. From the entropy law, we know this to be untrue. That is, the quality of energy (capacity to perform mechanical work) is the central measure of importance in thermodynamics. Under a system of thermodynamic measurement, energy commodities would be arrayed from pure work (electricity) through successively lower grades (high pressure steam, hot water), down to ambient. In terms of energy quality, a process is deemed efficient if the energy used in terms of both quality and quantity is properly matched to the requirement of the process.

In the case of ethanol manufacture, this can be seen clearly when one notes that the temperatures required for the process are generally below the boiling point. Thus, the heat requirement for the process can be supplied almost entirely by the "waste" heat of electricity manufacture, food processing, etc. The capacity of such low temperature heat to perform work is quite low though its joule content may be great. The alternative uses of low grade heat are limited by lack of transportability and the inability to perform work. Thus, the use of such energy to assist in the manufacture of a fuel capable of performing work is clearly advantageous from a thermodynamic perspective.* A properly designed ethanol plan, then, would utilize low grade heat wherever possible so that the actual joule-in/joule-out balance would be largely irrelevant.

*The second law efficiency is given by

$$
\mathrm{e}=\left(\mathrm{B}_{\min } / \mathrm{B}_{\mathrm{Q}}\right)<1
$$

where $B_{\min }$ is the minimum quantity of work that is required by the process and $B_{a}$ is the actual value of available work in that process. Thus, the value of e shows whether a process is using too much work (high quality energy) relative to that which is required by the physical description of the process. Work, as an index of the quality of energy, does not appear in the first law efficiency measure, $n=$ outputs/inputs. In fact, the two measures are literally independent so that optimization of net energy efficiency will not assure that available work is being used effectively [6, Ch. 3]. Applying this reasoning to the present case, we find that the preoccupation with quantitative output-input ratios blinds us to the fact that a properly designed ethanol facility mostly would use energy that cannot perform work at a very great efficiency, and it would turn out two or more high quality products including a fuel that is capable of performing mechanical work. 
SEPI 
SECTION 3.0

\section{AGRICULTURAL POLICY AND FOOD PRODUCTION IMPACTS}

Deterioration of prices for major export crops combined with the continuous devaluation of the dollar and oil price increases since 1975 has made U.S. agriculture less productive in terms of oil import capacity. The solutions to this problem require that the United States increase the value of its agricultural exports while at the same time substituting for some of the imports of oil. One obvious short term tactic is to artificially increase the prices of major feed grains by restricting production. Since the short-run demand is relatively inelastic, such a tactic would seem to hold the promise of increased export earnings. In the longer-run, however, such policies will not work and in fact may do more har $m$ than good since longer run elasticities are higher than the short-run ones. In addition, much of the export demand is for feed grains for which the demand elasticities are greater than for food grains.*

As shown in Table 3-1, the long-run export demand elasticities of major feed and food exports are sufficiently large so that a relative price increase of these crops with respect to other goods would lead to a drop in total export revenue. It is important to note that the domestic demand for wheat and soybeans is inelastic even in the long run. Therefore, policies designed to raise food and feed prices would lead to a decrease in the value of agricultural exports while, at the same time, causing food price inflation in this country. From an economic perspective, then, a set of policies designed to coproduce energy and food should proceed to the point at which the decrease in food export value is just matched by the replacement effect on energy supplies of the production of energy from agriculture.**

*If the elasticity of demand for a product is greater than unity then an increase in quantity supply price will induce a more than proportionate decrease in demanded. The total revenue $(p \times q)$ will fall from its former level as a result of the price increase. This argument is laid out in lavish detail by Joan Robinson ("Beggar - My - Neighbour Remedies for Unemployment," Essays on the Theory of Employment, Oxford, 1947) and Tibor de Scitovsky ("A Reconsideration of The Theory of Tariffs," Review of Economic Studies, 1942 , pp. 89-110, see especially sections I and II).

** This is easily shown mathematically. Suppose that the export balance from the agricultural sector $x(f)$ equals food exports, e, minus the export loss due to increased prices from diversion of crops to energy production $c(f)$,

$$
\text { i.e., } x(f)=e-c(f) \text {. }
$$

Now suppose further that oil imports, $\mathrm{m}(0)$, are composed of total import demand a(o) minus the displacement of imported oil by agriculturally derived fuels $\mathrm{d}(\mathrm{f})$,

$$
\text { i.e.; } m(0)=a(0)-d(f) \text {. }
$$

If the relevant trade balance is represented by

$$
B=x(f)-m(0)
$$

then a simple maximization of B over available agricultural-energy options will yield 
Table 3-1. DOMESTIC AND EXPORT DEMAND ELASTICITIES FOR FOOD AND FEED GRAINS ${ }^{a}$

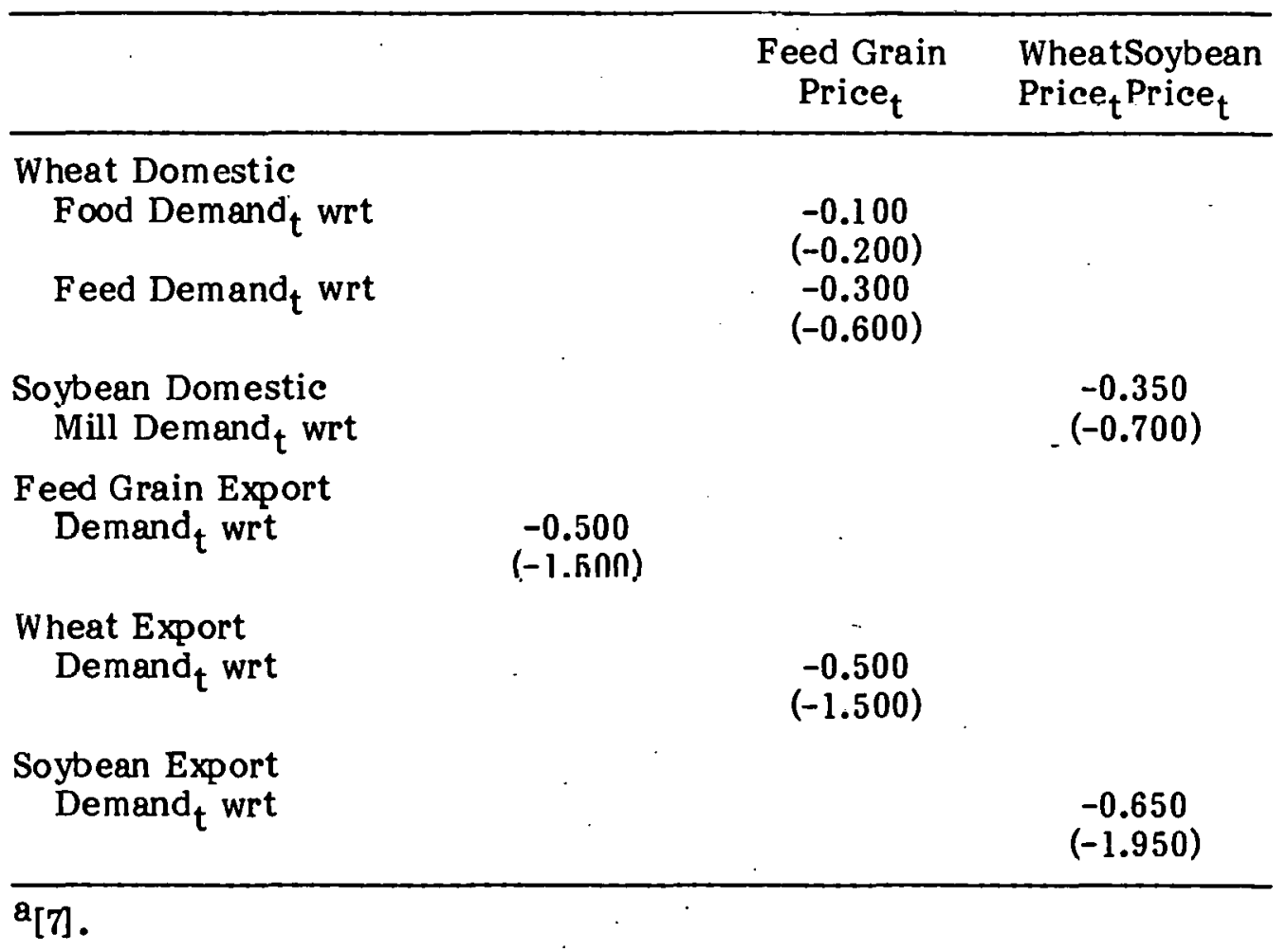

the requirement that

$$
\frac{\partial B}{\partial f}=-c^{\prime}+d^{\prime}-0 . \Leftrightarrow d^{\prime}=c^{\prime}
$$

If $c^{\prime}>d^{\prime}$ then the net gain from diverting crops to energy production is negative. Thus

$$
\frac{d^{\prime}}{c^{\prime}} \geqq 1
$$

is a requirement for feasibility. If

$$
\frac{d^{\prime}}{c^{\prime}}>1
$$

then the value of B can be increased by further diversion of crops to energy. 
There are, of course, other reasons why the United States would find it desirable to incur a net loss in export revenue in order to boost domestic production of energy. Foremost among these are national security and foreign policy considerations. Secondarily, increased domestic production will help to stabilize the value of the dollar. Calculating the opportunity costs in terms of oil import capability provides an interesting exercise in energy and economic analysis that indicates one area of possible usefulness for the energy balance concept.

To indicate how such an exercise can be done, we first need to consider briefly the nature of the U.S. grain export markets. Table 3-2 shows the importance of exports for the five major food and feed crops: wheat, rice, soybeans, sorghum, and corn. At least a quarter and as much as half of some of the crops are exported and comprise a large share of all the grain in international trade. (Cotton and tobacco provide similar foreign trade benefits but are not directly relevant to this paper since they are largely independent of the feed-grain markets, with the exception of cottonseed meal.)*

Table 3-2. U.S. GRAN AND FEED EXPORTS, 1974-76 ${ }^{\mathrm{a}}$

\begin{tabular}{|c|c|c|c|}
\hline & 1974 & 1975 & 1976 \\
\hline \multicolumn{4}{|l|}{ Wheat } \\
\hline $1,000 \mathrm{M}$ tons & 28,039 & 31,522 . & 25,731 \\
\hline Percent of U.S. crop & 48.3 & $\quad 54.1$ & 46.7 \\
\hline Percent of total world exports & 43.8 & 47.2 & 40.2 \\
\hline \multicolumn{4}{|l|}{ Rice } \\
\hline $1,000 \mathrm{M}$ tons & 1,702 & 2,070 & 2,045 \\
\hline Percent of U.S. crop & 29.3 & 39.0 & 45.5 \\
\hline Percent of total world exports & 21.5 & 28.9 & 24.3 \\
\hline \multicolumn{4}{|l|}{ Corn $^{b}$} \\
\hline $\begin{array}{l}1,000 \mathrm{M} \text { tons } \\
\text { Percent of U.S. crop }\end{array}$ & $\begin{array}{r}35,929 \\
24.4\end{array}$ & $\begin{array}{r}46,421 \\
29.4\end{array}$ & $\begin{array}{r}43,505 \\
26.9\end{array}$ \\
\hline \multicolumn{4}{|l|}{ Sorghum $^{b}$} \\
\hline 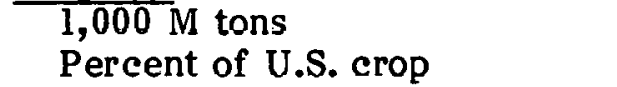 & $\begin{array}{r}5 ; 396 . \\
34.0\end{array}$ & $\begin{array}{r}5,829 \\
30.4\end{array}$ & $\begin{array}{r}6,262 . \\
34.2\end{array}$ \\
\hline \multicolumn{4}{|l|}{ Soybeans $^{b}$} \\
\hline $1,000 \mathrm{M}$ tons & $11,473.7$ & 15,138 & $915,383.7$ \\
\hline Percent of U.S. crop & 27.1 & 43.1 & 32.9 \\
\hline
\end{tabular}

*The acreage allotment programs for cotton and tobacco effectively ensure the existence of rents for the owners of the allottments. This effectively segregates the land market in areas where these crops are grown such that the entire allottment is utilized in most years. 
With U.S. oil imports running at about 8 million barrels per day currently, the United States exports of these five crops account for more than $20 \%$ of the value of oil imports, as shown in Table 3-3. The purpose of the energy-economic analysis is to determine the opportunity costs of increased energy production from agriculture with respect to possible reductions in export earnings through decreased supply and/or higher prices.

Table 3-3, VALUE OF U.S. GRAIN AND FEED EXPORTS, 1974-76 ${ }^{\mathrm{a}}$

\begin{tabular}{|c|c|c|c|}
\hline & 1974 & 1975 & 1976 \\
\hline \multicolumn{4}{|l|}{ Wheat } \\
\hline $\begin{array}{l}\text { Season Average Price/bu. } \\
\text { Value of Exports }\left(\$ 10^{6}\right) \\
10^{6} \text { Barrel of Oil Equivalents } b\end{array}$ & $\begin{array}{r}4.09 \\
4,505.3 \\
386.7\end{array}$ & $\begin{array}{l}3.56 \\
4,408.6 \\
378.4\end{array}$ & $\begin{array}{l}2.73 \\
2,759.6 \\
204.4\end{array}$ \\
\hline \multicolumn{4}{|l|}{ Rice } \\
\hline $\begin{array}{l}\text { Season Average Price } / C W \overline{\mathrm{T}} \\
\text { Value of Exports }\left(\$ 10^{6}\right) \\
10^{6} \text { Barrel of Oil Equivalents }\end{array}$ & $\begin{array}{c}11.20 \\
419.4 \\
36.0\end{array}$ & $\begin{array}{l}8.35 \\
380.3 \\
32.6\end{array}$ & $\begin{array}{r}7.02 \\
315.8 \\
23.4\end{array}$ \\
\hline \multicolumn{4}{|l|}{ Corn } \\
\hline $\begin{array}{l}\text { Season Average Price/bu. } \\
\text { Value of Exports }\left(\$ 10^{6}\right) \\
10^{6} \text { Barrel of Oil Equivalents }{ }^{b}\end{array}$ & $\begin{array}{r}3.02 \\
4,262.7 \\
365.9\end{array}$ & $\begin{array}{l}2.54 \\
2,632.2 \\
366.2\end{array}$ & $\begin{array}{l}2.15 \\
3,674.6 \\
272.2\end{array}$ \\
\hline \multicolumn{4}{|l|}{ Sorghum } \\
\hline $\begin{array}{l}\text { Season Average Price/bu. } \\
\text { Value of Exports }\left(\$ 10^{6}\right) \\
10^{6} \text { Barrel of Qil Equivalents }\end{array}$ & $\begin{array}{l}2.77 \\
587.2 \\
50.4\end{array}$ & $\begin{array}{r}2.37 \\
542.7 \\
46.6\end{array}$ & $\begin{array}{r}2.03 \\
499.4 \\
37.0\end{array}$ \\
\hline \multicolumn{4}{|l|}{ Soybeans } \\
\hline $\begin{array}{l}\text { Season Average Price/bu. } \\
\text { Valuc of Exports }\left(\$ 10^{6}\right) \\
10^{6} \text { Barrel of Oil Equivalents }\end{array}$ & $\begin{aligned} & 6.64 \\
& 2,793.5 \\
& 239.8\end{aligned}$ & $\begin{array}{rl} & 4.92 \\
2,131.1 & 234.4\end{array}$ & $\begin{array}{r}6.81 \\
3,841.3 \\
284.5\end{array}$ \\
\hline \multicolumn{4}{|l|}{ Total } \\
\hline $\begin{array}{l}\text { Value } \\
10^{6} \text { Barrel of Oil Equivalents }\end{array}$ & $\begin{array}{r}12,568.1 \\
1,042.8\end{array}$ & $\begin{array}{r}12,694.9 \\
1,058.3\end{array}$ & $\begin{array}{r}11,090.7 \\
82.1 .5\end{array}$ \\
\hline
\end{tabular}

a[8].

${ }^{b}$ Priccs uscd were $\$ 11.65 / \mathrm{bbl}$. for 1974 und $1975, \$ 13.50 / \mathrm{bbl}$. for $1 \overline{9}^{7} 76$.

The technique is quite simple; it is used to arrive at the figures given in Tables 3-4 and 3-5. The direct substitution of ethanol for gasoline (assume $1: 1$ ) is a straightforward calculation. Any sizable ethanol program will give rise to large quantities of the DDG feedgrain (see Table 2-1 for proportions). For expository purposes it is assumed that all of the additional DDG is exported at a price equivalent to the current market price. As can be seen from Table $3-4$, a relatively modest ethanol program will displace about three days of oil imports while a larger program will displace more than one week of imports. 
Table 3-4. ENERGY-IMPORT TRADEOFFS OF A GASOHOL
PROGRAM WITH EXPORT OF DDG

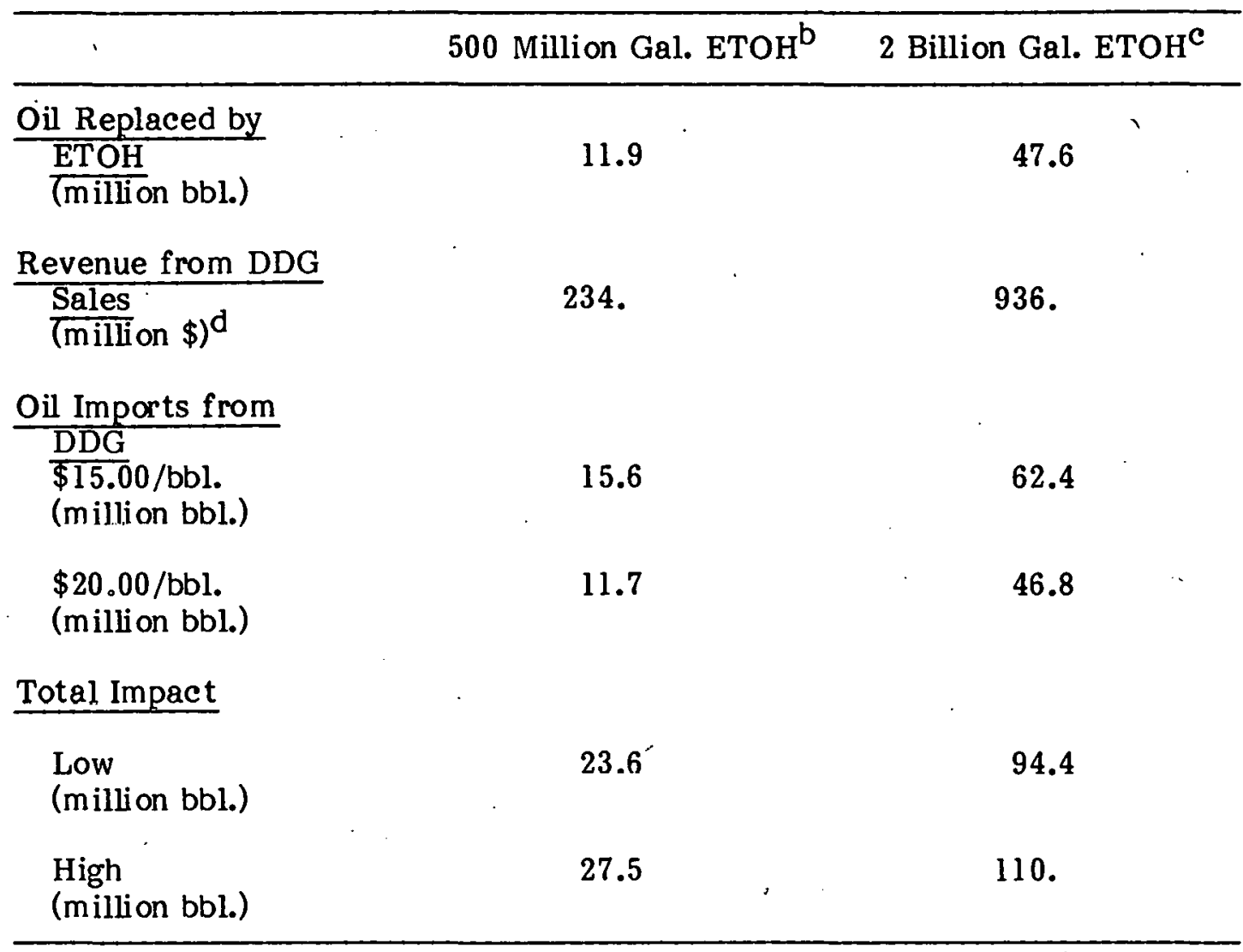

${ }^{a}$ Calculated by author from previous tables.

$\mathrm{b}_{1.8}$ million tons of DDG: at $100 \mathrm{bu} / \mathrm{acre}$, this would require 2 million acres.

$c_{7.2}$ million tons of DDG: at 100 bu/acre, this would require 8 million acres. $\mathrm{d}_{\$ 130 / \text { ton. }}$ 


\section{Table 3-5. NET LIQUID ENERGY TRADE IMPACTS} OP A GASOHOL PROGRAM AS ABOVE ${ }^{\mathrm{a}}$

\section{Million Gal. ETOH 2 Billion Gal. ETOH}

Growing Energy

Low $^{\mathrm{b}}$

4.6

18.4

(million bbl. of oil equiv.)

6.5

26.0

High $^{\mathrm{e}}$

(million bbl. of oil equiv.)

Net Oil Replaced

Low -

17.1

68.4

(million bbl.)

High

23.8

95.0

(million bbl.)

Low

(bbl. per acre) $^{d, e}$

High

(bbl. per acre) $)^{d, e}$

11.9

11.9

${ }^{a_{A}}$ Assume that renewable energy resources are used for processing ethanol [9].

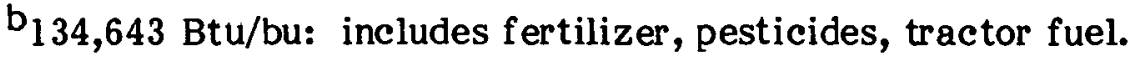

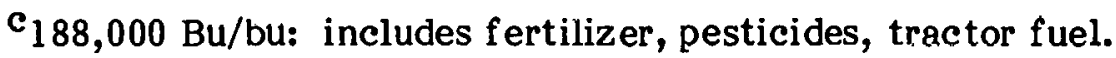

$\mathrm{d}_{\text {Assumes } 100 \mathrm{bu} / \text { acre yield. }}$

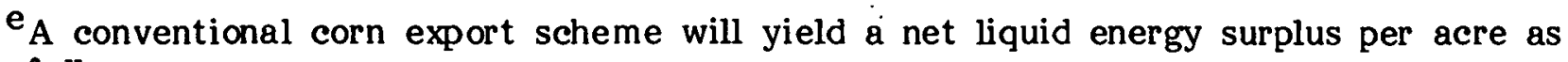
follows:

Gross Oil Imports/a (bbl) $\quad$ Net Energy Imports/a (bbl)

Growing Energy

$\mathrm{bbl} / \mathrm{a}$

nil at Dil at

$\$ 15 / \mathrm{bbl} \quad \$ 20 / \mathrm{bbl} \quad \$ 15 / \mathrm{hhl} \quad \$ 20 / \mathrm{bbl}$

$\begin{array}{lllcccc}\text { Low } & \text { Higl } & \begin{array}{l}\text { Corn at } \\ \$ 2.25 / \text { bu }\end{array} & 15 & 11.3 & 11.8-13.2 & 8.1-9.5 \\ 2.3 & 3.2 & & & & \\ & & \begin{array}{l}\text { Corn at } \\ \$ 3.50 / \text { bu }\end{array} & 23.3 & 17.5 & 20.1-21.5 & 14.3-15.7\end{array}$


Programs of such magnitude as described above and in Table 3-4 are as large as practicable for the near term in the United States short of a crash construction program. The addition of 500 million gallons of annual capacity to the existing fermentation capacity for nonbeverage uses of about 40 million gallons per year would imply the construction of at least 420 million gallon plants each year between now and 1985. Such activity is possible, though initially much of the increased alcohol capacity will come from upgrading and modemization of old fermentation plants from the World War II period in which much of the U.S. industrial alcohol capacity came from fermentation.

Though the apparent impact on energy supplies from a 2 billion gallon program appears to be slight, the impact on agricultural markets is not. In fact, this program would require a significant expansion of corn acreage and would increase the availability of DDG by more than one order of magnitude. Thus a successful alcohol program would require export of at least some of the DDG or equivalent amounts of other feeds (see below for the estimation of the price relations of the markets in which DDG competes).

To obtain the figures given in Table 3-5 conceming the net liquid energy trade impacts of the two gasohol alternatives, take the growing energy (from Table 2-2), and calculate the total for the 500 million gallon and 2 billion gallon programs. Next, get the gross oil displacement including sale of the DDG (from Table 3-4) and subtract the growing requirement from the gross displacement. This gives the net oil displacement as supplied in Table 3-5.

For a $500 \mathrm{milli}$ on gal/yr ethanol program, the direct displacement of oil is $500 \mathrm{million}$ gallons or 11.9 million barrels. Exporting the entire production of DDG at $\$ 130 /$ ton will yield $\$ 234$ million, permitting an additional 11.7 million barrels of oil at $\$ 20.00$ per barrel. The total of these two figures is 23.6 million barrels. The energy to grow the crops for this project will take 4.6-6.5 million barrels of oil so that the net replacement effect of the progrm would be 17.1-19.0 million barrels annually at $\$ 20.00$ per barrel.

For purposes of comparison with conventional corn export schemes, the impacts have been computed on a per-acre basis under the implicit assumption that the grain f.or ethanol is grown on good quality agricultural land. Thus, the figures for programs that aid to utilize set-aside or other poor quality lands will be less attractive since the growing energy will increase while the yields will decrease.

Table 3-5 presents a best case for grain alcohol in that both favorable growing conditions and complete, high-value utilization of the DDG by-product are assumed. Using the data from Table 3-5 as a base case, consider the variations around those figures that could easily arise. First, consider the implications of using poorer or even average land for growing the grain. In 1977 the U.S. average yield per acre for corn was 90.8 bushels/acre (4.58 tons/hectare). Lands that are in set-asides or are not now in production would presumably yield less than the average figure. Since a certain amount of energy must be devoted to the agricultural operations regardless of the yield, the figure for net liquid energy balance is likely to deteriorate with increased use of poor quality lands for the corn used for alcohol production. The next variation to consider is the possibility that the price of DDG as an animal feed could deteriorate with increased amounts of the product coming on the market. At the present time, the price of DDG is set by a formula that relates it to the prices of soybean meal, cottonseed meal, and wheat bran. Since significant amounts of DDG would obviate the role that bran plays in the markets, its value would drop. However, this would decrease the value of the fiber portion of the DDG as well, thereby leading to an overall deterioration in the price of the DGG. These relationships are reported in the appendix. 


\subsection{AGRICULTURAL POHCY}

One of the major claims made by the supporters of grain alcohol programs is that there are $\mathrm{x}$ or $\mathrm{y}$ million acres available for the production of energy crops since about 10 million acres are currently in set-asides and a much larger, though uncertain, number of acres is available in the form of cropland that is currently in pasture. There are two policy alternatives that would make more production available for energy crops. The first al ternative is simply to eliminate the set-aside programs for fecd and food grains and to maintain a loan program in the expectation that the increased demand for grain from the fermentation industry would maintain a price for grains that is sufficiently remunerative to keep the land in production. The second alternative is to maintain the set-aside provisions and to earmark that production which comes from those acres as feedstock for energy production only.* Under this alternative the farmers would be paid as under the set-aside program and would be required to sell. their output to the government at a fixed, below-market price. As explained below, this price is equivalent to the cost of production plus normal profits (including land charge). The variable costs (fuel, seed, chemicals, fertilizer, labor) would be paid at the purchase time. The remainder (fixed charges) would be included in the set-aside payment itself. The government would, in turn, sell this grain to alcohol producers at a price below market clearing.

What are the implications of these two alternative policies? Looking at the first alternative, it can be seen that the major advantage lies in the simplicity of the program. That is, there are no major administrative costs to the program. The major drawback is equally simple. This policy fails to account for the prime reason that agricultural support programs exist at all; that is the persistent imbalance between the farmers' capacities to produce and the effective demand on the national and world markets. It is possible that in 5-10 years the ethanol market may be sufficiently equilibrated so that the amount of grain taken for fermentation will be well known prior to the planting season, but such is not the case presently. Thus, while being beneficial for the ethanol producers, this program essentially does nothing for the persistent problem of excess farm production since there obviously are circumstances under which the loan programs would be insufficient and actual storage and purchase would be necessary.

The second alternative clearly will be more advantageous for farmers than the former alteirnative. The set-aside program guarantees the farmer a given rate of return for the participating acres; i.e., the set-aside payment covers the land charge plus fixed expenses. Thus, if the government were to purchase the grain that is produced on that land for its cost of production (minus land charge), then the farmer would have a guarantee of making "normal profits" on that acreage. The big disadvantage of this policy from the point of view of the alcohol producer is uncertainty. If farmers generally expect a good

*The set-aside program is a voluntary program that pays farmers to leave a certain proportion of their acreage, normally put into food or feed grains, idle. As an alternative, the farmers may grow crops that are not under the provisions of the set-aside act or may use those acres as pasture. Since the program is voluntary, there is always an incentive for lower-cost producers to not participate in the program so that the set-aside acreage is usually less than the full proportion of the land that is in the subject crop. For example, if low-cost producers believe that the price of the grain will not fall below a certain profit margin above their production costs, then they will have no incentive to participate in the program. Of course, this extra production will ensure that the price is lower than it would have been otherwise. 
year in terms of prices, then participation in the set-aside programs will be low and the availability of inexpensive grain to ethanol producers will be low also. It is this uncertainty more than anything else that makes the second alternative risky from the viewpoint of energy production.

Since agricultural policies can have great eff ects on both the prices at which agricultural commodities are sold and the amounts available to the market, it is instructive to consider the cost elasticities of ethanol from grain. The cost elasticity is defined as the proportional change in the cost of output divided by the proportional change in the price of one input; i.e., cost elasticity $=\partial \ln C / \partial \ln r_{i}$, where $r_{i}$ is the price of input $i$ and $C$ is unit cost. Using data on the sensitivity of ethanol price to various corn and wheat prices, the results shown in Table 3-6 are found.

Table 3-6. COST ELASTICITY OF ETHANOL ${ }^{\mathrm{a}}$

\begin{tabular}{|c|c|c|}
\hline Price Range & Corn & Wheat \\
\hline $\begin{array}{l}\text { Low } \\
\quad\left(\$ 1.50-1.75 / \mathrm{Bu}_{.}\right)\end{array}$ & 1.2 & 1.3 \\
\hline $\begin{array}{l}\text { Medium } \\
\quad(\$ 2.50-3.00 / \mathrm{Bu} .)\end{array}$ & 1.1 & 1.0 \\
\hline $\begin{array}{l}\text { High } \\
\qquad(\$ 4.00-4.50 / \mathrm{Bu} .)\end{array}$ & 0.8 & 0.79 \\
\hline
\end{tabular}

Until grain prices get very high, a $1 \%$ increase in the price of grain will cause a more than proportionate shift in the price of fermentation ethanol. This high value for the cost elasticity is one reason that grain alcohol can be expected to be a limited phase in the development of liquid fuels from renewable resources.

\subsection{LMIIATIUNS}

Predicting the future is a risky business, under the best of circumstances. The coupling of food and energy resources increases the potential volatility of the agricultural markets since an increased proportion of total U.S. production will come from lands on which the yields are difficult to predict. In addition, technological uncertainty with respect to both the nature and the timing of cellulose conversion technologies makes predictions of the eventual extent of energy crop production difficult. 
In order to lessen some of these uncertainties, SERI plans to utilize an agricultural sector model, POLYSIM, to simulate the operation of agricultural markets under alternative demand situations. The results of this model will be used to determine the short-run impacts of alternative energy and agricultural policies on food prices, farm income, exports, and livestock prices.* The use of POLYSIM will improve the quantitative estimates given in Tables 3-4, 3-5, and 3-6 on some of the macroeconomic impacts of energy production from agriculture.

An additional element of realism that will appear in subsequent work is the inclusion of land availability according to price-cost of production relationships so that we may better estimate the availability of additional production at various levels of demand and price. A detailed report on the price relationship for DDG and gluten meal is fortheoming.

*The POLYSIM model is a simultaneous equation model that uses historical estimates of demand and supply functions to solve for prices, quantities, acreages of various crops, and government payments. It does not contain any implicit assumptions about behavior in the agricultural sector and is, therefore, a short-term model rather than a predictor of long-run behavior. 


\section{SECTION 4.0}

\section{CONCLUSIONS}

Ethanol from grain has the potential to be a significant source of energy in the short term with reasonable costs vis-a-vis other sources of liquid energy, particularly given the credit for the by-products. A major effort to produce ethanol in the short run (before 1985) is not likely to have a significant impact on farm prices or exports since the potential for building up the industry from zero is such that slack lands are likely to be available at least until 1985. In addition, the entire production of at least one large-scale grain ethanol plant could be used to eliminate the current trade deficit in industrial ethanol of about 20 million gallons per year. (Table 4-1).

Table 4-1. U.S. SYNTHETIC ALCOHOL PRODUCTION AND CONSUMPTION ${ }^{\mathrm{a}}$

\begin{tabular}{|c|c|c|c|c|c|}
\hline & & \multicolumn{4}{|c|}{ Ethanol } \\
\hline & 1978 & 1977 & 1976 & 1975 & 1967 \\
\hline $\begin{array}{c}\text { Production } \\
10^{8} \mathrm{gal} .\end{array}$ & 1.87 & 1.91 & 2.2 & 2.1 & 2.8 \\
\hline $\begin{array}{l}\text { Exports } \\
10^{6} \mathrm{gal} . \\
10^{6} \begin{array}{l}\$ 6.163\end{array}\end{array}$ & $\begin{array}{l}7.077 \\
5.889\end{array}$ & 6.501 & & & \\
\hline $\begin{array}{l}\text { Imports } \\
10^{6} \mathrm{gal} . \\
10^{6} \$ 18.3\end{array}$ & $\begin{array}{l}22.9 \\
13: 1\end{array}$ & 19.2 & & & \\
\hline \multicolumn{6}{|c|}{$\begin{array}{l}\text { Domestic Consumption } \\
10^{6} \mathrm{gal} \text {. }\end{array}$} \\
\hline & Current price: & $\begin{array}{l}\$ 1.25 / \text { gal. }\left(190^{\circ}\right) \\
\$ 1.35 / \text { gal. }\left(200^{\circ}\right)\end{array}$ & & & \\
\hline
\end{tabular}

With continuously declining domestic production of ethylene-based industrial ethanol, the potential for grain alcohol appears to be great. The current subsidies to gasohol make the fuel competitive, or nearly so, with unleaded gasoline. The rising price of gasoline combined with a fall in ethanol prices which would be expected in the wake of increased production of ethanol, should mitigate the possibility of needing large and growing subsidies to the industry. On the other hand, at some time the production of ethanol from grain will begin to tighten agricultural markets and lead to price increases.

At what point this will happen is not clear. An additional 500 million gallons of ethanol production capacity by 1985 would require that at least five 20 million gallons/year plants arc constructed every year between now und 1985. With this level of ethanol production, one might expect some impacts on traditional agricultural markets. Howev- 
er, by 1985 good technologies for conversion of cellulose to alcohol should be available. In addition, research on the use of unconventional dryland or aquatic crops should have yielded some useful results by that time.

Further emphasis on grain after the short-run period appears to be unwise, given the potential for adverse impacts on agricultural trade. There is good reason, then, to be optimistic about the potential for short-run results from ethanol derived from grain. The longer term problems may be mitigated by both new technologies and market outcomes (e.g., rising prices for grains and increased foreign sales resistance). More precise and detailed answers to many of these questions should be forthcoming from research presently underway and due to be completed by the end of the summer. 


\section{REPERENCES}

1. Lipinsky, E.; et al. Fuels from Sugar Crops: Report of Systems Study of Sugar Cane, Sweet Sorghum, and Corn. Columbus, OH: Battelle Laboratory; 1978.

2. D. Burbett, ADM Company. Personal communication; 21 February 1979.

3. Resources and Energy. Vol. 1: pp 151-204; 1978.

4. Kendrick, W.; Murray, K. Grain Motor Fuels: An Evaluation. Lincoln, NB: University of Nebraska; 1976 .

5. Litterman, M.; Eidman, V.; Jensen, H. Economics of Gasohol. Minneapolis, MN: University of Minnesota; 1979.

6. Hertzmark, D. I. "Economics, Thermodynamics, and the Allocation of Energy." Unpublished Ph.D. dissertation; University of Wisconsin; 1978.

7. Oklahoma State University. Detailed Description of Polysim. Stillwater, OK: Oklahoma State U.; 1978.

8. U.S. Department of Agriculture. Agricultural Statistics 1978. Washington, D.C.: U.S. Government Printing Office; 1978.,

9. Smith, R.S.; Miranowski, J. A.; Vetter, R. L. Energy Relationships for a 320 Acre Iowa Farm. Ames, IA: University of Iowa; 1978.

10. Chemical and Engineering News. pp. 46-47; 12 June 1978.

11. Chemical Marketing Reporter. p. 15; 19 March 1975. 


\section{SEPI}




\section{APPENDIX \\ THE MARKETS FOR DISTHLERS' BY-PRODUCTS}

In this appendix, the current markets for fermentation by-products and possible structural changes that may ensue from increased ethanol production are discussed briefly. Distillers' dried grains (DDG) is one of several by-products that make up the residual elements in the commercial feed market. The other members of this group include brewers' dried grains (BDG), corn gluten meal, and several animal by-products. According to the Allied Products Manager of Adolph Coors Company, George Wornson, these by-products are priced by a formula that relates the price of BDG to that of soybean meal, cottonseed meal, and wheat bran.*

According to Wornson, the price of BDG is determined by the composite price of an equivalent protein product, soybean meal and bran or cottonseed meal and bran. A similar method of pricing for DDG was assumed. If soybean meal (.49 protein) and wheat bran (.15 protein) are mixed to obtain the DDG equivalent (.28 protein), the resulting mixture will be .38 soybean meal and .62 bran. If soybean meal is $\$ 218 /$ ton and bran is $\$ 80 /$ ton, then the resulting mixture will cost about $\$ 128 /$ ton at .28 protein equivalent. Similarly, a mixture of cottonseed meal (.4l protein) diluted with bran to .28 protein would cost $\$ 128 /$ ton with cottonseed meal at $\$ 175 /$ ton (.51 cottonseed meal, .49 bran). The equilibrium price of DDG at this location would be $\$ 130 /$ ton. In 1976 the actual price of DDG was $\$ 132 /$ ton.

The stability of these relationships was tested with econometric estimating equations of the form

$$
P_{i}=\sum_{j=1}^{H} B_{j} P_{j}+\epsilon
$$

price forecasting equations for the dependent prices, $P_{i}$, and the explanatory prices, $P_{j}$. A detailed reporting of the results is forthcoming. For now, note that the movements of the prices of soybean meal, cottonseed meal, wheat bran, and corn were consistently able to explain more than .9 of the movements in the prices of DDG, BDG, and corn gluten meal.

The results outlined above indicate that, as long as the structure of the commercial feed market remains in its present form, then DDG and corn gluten meal will be high value by-products of energy production. Eventually, increases in DDG production could prove sufficient to devalue bran as a mixer for soybean meal, thus leading to a price decrease. Should this happen, then the price of DDG will also fall, lessening its attractiveness as an energy coproduct. Alternative product routes, such as corn oil, pharmaceuticals, and human foods, may obviate this though more work is needed to identify the quantities of DDG that would start to have serious impacts on feed prices.

\footnotetext{
*Personal communication; 22 January 1979.
} 


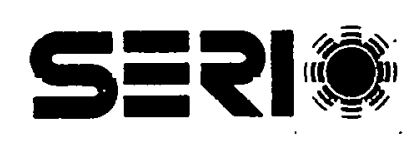




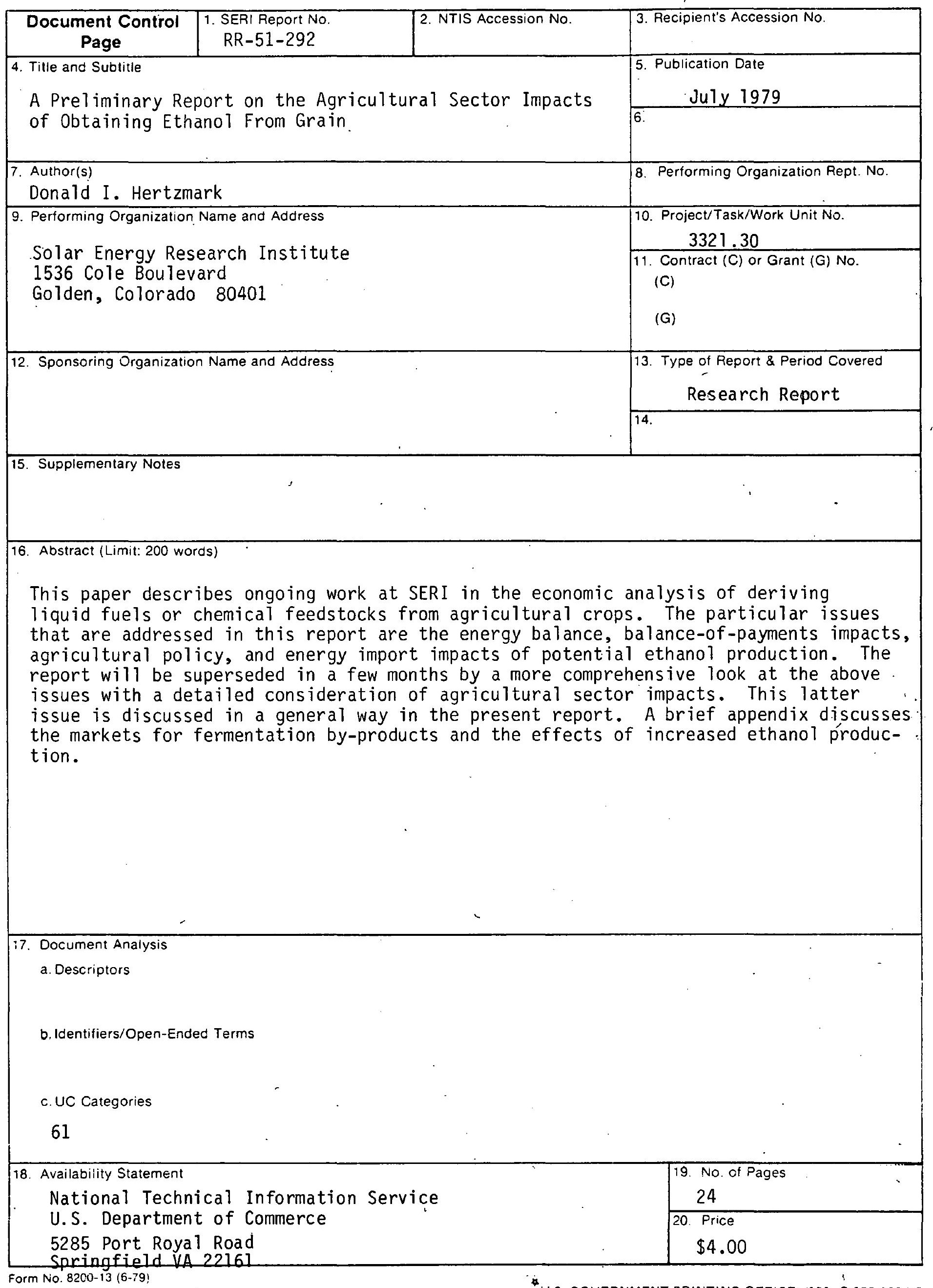

